\title{
П'єр Коса
}

\section{«ЧИ МОЖЕ НАЦІОНАЛЬНА ФІЛОСОФІЯ БУТИ ТОЧНО ВИЗНАЧЕНИМ ДОСЛІДНИЦЬКИМ ОБ'ЄКТОМ?» ПРИПЛИВИ Й ВІДПЛИВИ МІЖ ЄДИНИМ (СПІЛЬНИМ) І МНОЖИННИМ (РОЗРІЗНЕНИМ)}

Замість встуnу. - Питання це $є$ не просто гострим, воно провокативне, сповнене апорій і парадоксів. Якщо сформулювати його так, останні постають одразу ж, варто лише зіставити два протилежні його прочитання.

Терміни, що його складають, у звичайному прочитанні (якщо читати фразу зліва направо) наражаються на суцільну низку проблем. «Національна філософія» рішуче зіштовхується зі славетною ідеєю «philosophia perennis» (яка, поза сумнівом, є не «наукою», а лише «любов’ю до мудрості»), відкриваючи поле для численних способів діяти й намірів; останні ж $є$ ніби намагніченими тим «трансцендентальним» горизонтом, що підноситься понад національними суперечностями, стосовно яких одразу ж виникає підозра в редукціоністській упередженості. Як наслідок - хитання між визначеним («la») і невизначеним («une»), між концептом (універсальним) та одиничною індивідуацією; й відтак усе, що ми приписуємо цій останній, передбачає визнання деякого стилю, деякого ненаслідовного способу філософувати, що імпліцитно передбачає існування відмінних культур; узятий у такий спосіб, «об'єкт дослідження» орієнтується на філологічну, ба навіть етнологічну розвідку, що може «визначатися» лише, наприклад, у горизонті умовної «структурної антропології». Відповідь на поставлене питання тоді буде рішуче негативною.

Але можна спробувати вдатися до протилежного прочитання, що йде, навпаки, від кінця фрази до ії початку. Якщо відштовхуватися від «точно визначеного», це передбачає суворий порядок концепту й теорії; тоді дослідження покладає собі «онтологічний» намір, горизонт якого - визнання філософії як радикально «національної». Ненаціональна (транснаціональна, наднаціональна) філософія постала би тоді чистою фікцією, химерною фантазією самотнього мислителя-мрійника (Schwärmer'a, якщо вжити термін, популяризований Кантом), який не мав би іншого виходу, окрім удаватися до розпізнавання філософії, заснованого на якомусь її втіленні в просторі й часі.

Чи можна сподіватися на вихід 3 невизначеної й заплутаної гри цієї антиномії? Якщо філософія повинна 3 неї вийти, тоді вона може це, їй для того потрібно лише надати засоби. Але чи може цей варіант «категоричного імперативу» апелювати до

(C) П’єp Коса, 2014

(c) О. Хома, переклад з французької, 2014 
припису якоїсь водночас іманентної та радикальної рації, спроможної розвіяти завжди приховані спокуси якогось абсолютного рішення? Як уникнути цих розламів? Чи можуть ці дві течії зустрітися, ба навіть збагатити одна одну завдяки якомусь малоймовірному схрещуванню? Деякий його начерк маємо в патристичному дискурсі щодо «ангелів націй»: Бог відпочатково, за лаштунками світу, делегує Свою владу посланцям (ангелам), призначеним керувати різними націями. Добрими чи поганими останні виявляються залежно від чеснот чи пороків цих їхніх керівників. Але як інакше здати собі справу щодо поганих ангелів, окрім як припустити, що кожній нації властива деяка подвійність ангелів, відповідальних за той сповнений контрастів і амбівалентний хід справ, що визначає спрямованість мови й цивілізації кожного народу [див. Daniélou, 2012: p. 222-235].

Цей «міфопоетичний» розв'язок має принаймні ту безпосередню користь, що одразу ж занурює нас у велику дискусію між єдністю й множинністю, що міститься в самому серці проблем нації та не припиняє нас хвилювати.

\section{Від заспокоєності принципу (Сдине) до драматичних джерел множинності}

А. «Саме через Єдине всі сущі є тим, чим вони є... Яке суще існувало б, якби не було єдиним? Відокремлені від єдності, сущі не існували б» іi . Так починається остання з Плотінових Еннеад (VI, IX, 9 за класифікацією Порфирія); іï завершення виражає великий принцип, що проходить через увесь виклад Плотіна; йдеться про абсолютний, трансцендентний першопринцип, незвідний до будь-чого, що може претендувати на осяяння його світлом: Буття, Мислення, Душа й усе, похідне від

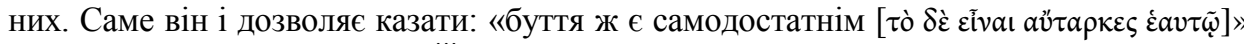
(VI, VI, 6, останній рядок) $)^{\text {iii }}$. Цей мотив був підхоплений Проклом: «Будь-яка

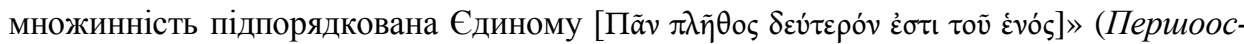
нови теології, § 5) ${ }^{\text {iv }}$. Сдине постає зовнішнім в усіх відношеннях, воно не має ані початку, ані середини, ані кінця; і якщо спробуємо наблизитися до його джерела, доведеться сказати, що це джерело - позабуттєве. Ми можемо лише наблизитися до нього, не маючи змоги говорити про нього.

Адже говоріння, «мова», це «феномен, позначений розрізненням... Вона діє як середній термін дискурсивного мислення, що може виголосити той сенс, який має передати, лише у взаємопов'язаності його елементів» [Beierwaltes, 1985: S. 102]. Звідси випливає, що про Сдине ми можемо говорити лише негативно, й, так само, мислити його можемо лише не мислячи його, тобто «реалізуючи думкою властиву їй здатність перевершувати саму себе й таким чином приводити в дію свою власну дорефлексивну основу» [ibid., S. 36]. Відтоді «мова завжди перебуває в парадоксі: бачення, яке $\epsilon$ не-баченням, мислення, яке $є$ не-мисленням, пізнання, що відбувається через не-пізнання» [ibid., S. 278]. У підсумку цих безперервних заперечень

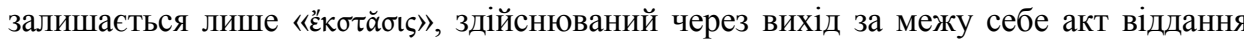
себе невидимій, невиразимій і настійливій присутності Єдиного. Таким чином неоплатонічний Всесвіт (точніше - Всесвіт неоплатонічного дискурсу), лише для того нескінченно відмовляється від змістовної щедрості слів (цілковито позначених відпочатковою злиденністю, яка живить і активізує їхнє невтомне й нездатне досягти результату напруження), щоби оголосити себе рішуче немічним. 
Немічність щодо завершення й могутність завжди поновлюваної активізації - ще один парадокс, - активізації, яка постійно підсилюється й на підмурку незавершеності вибудовує моменти деякої впорядкованої діалектики. Висловлюючись коротко й не відтворюючи докладної генеалогії, йдеться про ту саму роль, що переходить до Прокла, останнього представника тривалої традиції неоплатонізму, що підупадає та повертає до свого схоластичного витлумачення [traduction]. Ми зосередимося на лише одному, але засадовому елементі: йдеться про рішучу спробу прослідкувати внутрішній рух до Єдиного й викласти його узгоджені фази, згідно 3 пульсацією

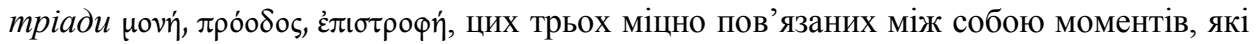
окреслюють повний цикл, або втілень Принципу, показаного в повноті його «життя». Моvท́ («нерухомість»), Принцип, схоплений у його джерелі, потуга максималь-

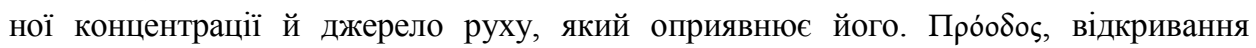
(«витікання»), рух виходу за межу себе, потуга, що на позір надає йому множинність, не послаблюючи його. Бо це «відкривання» готує повернення до себе

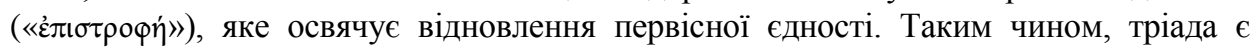
«засадовим законом буття, засадою мінливості та єдності космосу, принципом циклічного повернення світу до його засади» [Beierwaltes, 2000: p.171]. Плотін і Прокл (пов'язані тут у надто довільний спосіб) разом вказують на одіссею Нескінченного, яке відкривається скінченному лише заради повернення до Єдиного через постійне, безперервне опосередкування. Три фази тріади плинуть одна через одну й разом окреслюють коло, образ повного здійснення (системи). «Онтологічний принцип неоплатонізму... міститься в понятті proodos... в тому переконанні, що будь-яка річ спричиняє його в іншій, а це призводить до ії “витечення”... (виходячи з верховного Сдиного, початку всякого буття)... Коли ж вона хоче знову повернутися до Єдиного [epistrophè], то може це зробити лише через медитацію й пригадування свого власного найглибиннішого буття, адже в своїй глибинній засаді ця річ пов'язана із джерелом буття, розташованого понад нею й такого, від якого вона походить» [Ivanka, 1990: p. 241-242]. Витечення здійснюється без перерв і пауз. В «системі», яка поглинає всі свої моменти єдністю, що ніколи не ставиться під знак запитання, в «системі», де все розіграно наперед, немає нічого конфліктного чи драматичного. Тож можна 3 повним правом говорити про нічим не порушувану заспокоєність.

В. - Втім, говорячи про одиничне буття, про «самість», Е. фон Іванка наважується заявити: «його існування в якості створіння залишається... чимось таким, “чого не повинно бути"» [ibid., p. 76]. Проте така система, як неоплатонізм, не знає нічого, подібного до «створіння», адже останнє передбачає подію сотворення, тобто раптове з'явлення, що про нього ніяк не попереджалося («з нічого»), з'явлення, зумовлене лише вільною ініціативою. Тут впадають у вічі три головні риси: поява світу, не включеного у самодостатність Сдиного та спроектованого у відкритий простір, дистанційованого від свого творця і відмінного від нього. Цей світ населений «суб'єктами», буттями, що презентують «себе» в подвійному аспекті: як одиничні, що мають власне ім'я (первісток, Адам), і множинні, національні «суб'єкти» (нащадки Ноя, «що розселились... кожен за своєю мовою, за своїми племенами, у своїх народах» (Бут. 10: 5) ${ }^{\mathrm{v}}$ у відповідь на заклик Бога («будьте плідні, розмножуйтесь і розселюйтесь на землі та множтесь на ній; Бут. 9: 7»). Між Богом і «суб'єктами» ${ }^{\text {vi }}$ лежить опосередкування слова, що змушує їх перемовлятися шляхом відкритого й 
різноманітного діалогу. Маємо щось вельми протилежне неоплатонізмові. На цьому наголошує Байервальтес: «Неможливість самовисловлювання, що ії Єдине накладає на себе по відношенню до іншого (на основі розрізнювальної структури мови), конституює істотну різницю між плотінівським Сдиним і християнським Богом. Для останнього самовисловлюваність є конститутивною як усередині міжтринітарного стосунку, так і стосовно сотворення та одкровення» [Beierwaltes, 1985: p. 103, n. 2].

Але разом зі словом виникає ризик помилки, починаючи з першої спокуси в Раю та пізнішої драми, пов'язаної з Вавилонською Вежею, драми народу, що хоче набути владу, владу над світом, оперту на вежу, що $є$ прообразом його центру та виставляє себе як символ самообожування. Відтак втрата розуміння слів і розсіяння народів позначають, з погляду Бога, покарання за гордість, яка повторює ту спокусу, що вже сталася в раю («ви станете як боги»). Повернення до множини означає відновлення стосунків між створінням, - що мріє про Єдине і виявляється відновленим у своєму вихідному порядку, - і його Іншим, його Творцем, відновлення, що відбувається в діалоговому стосункові.

Це «покарання» виявляється подвійно добротворчим: відновлюючи між людьми ті зв'язки слова, що структурують живі спільноти (той випадок, коли саморозуміння $\epsilon$ водночас і самовибудовуванням), та запускаючи в дію ту історію, що приводить до одкровення в день П’ятидесятниці (тут на мене вплинула стаття Алейди Асман [Assmann, 1996]). Мови, визнані в їхніх розбіжностях, зазнали трансформації завдяки

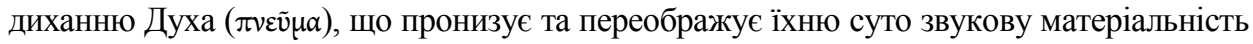
у безпосередньо ясний i завершений нематеріальний сенс. Середній термін знову схоплюється через звістку, звістку про спасіння, послану всім націям, що таким чином запрошуються сопричаститися в універсальній місії Духа. «Spiritus superbiae dispersit linguas, Spiritus sanctus congregavit linguas [дух гордості розсіює мови, Дух Святий згромаджує мови]» (св. Августин, Пояснення щзоо Псалмів 54: 11-12).

Але на цю мить (в історичному масштабі) зазначене «згромадження» є лише мрією, що відсилає до невимовного горизонту. Й історична реальність має взяти на себе встановлення історичного компромісу між невизначеною множинністю й точною єдністю; тоді відкривається тривалий епізод домінування «священних» мов (мов напису на хресті Розіп'ятого, Ін. 19: 20, Лк. 23: 38): гебрайської, грецької та латинської, що конкурували й сперечалися між собою, спокушені в свою чергу прагненням встановити своє власне верховенство та солідарні лише тоді, коли йдеться про відмову приймати в своє коло інші мови (парадигматичним випадком тут є старо-

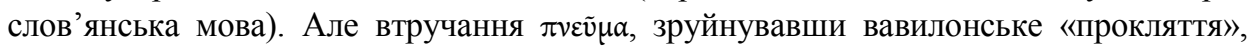
мабуть, не припинило запроваджувати різкі зміни й у прийдешню історію.

\section{Від П'ятидесятниці - до поновлення сутички в протистоянні між Мно- жинним і Єдиним}

А. - «Кара», що спостигла бундючні зазіхання Сдиного у Вавилоні, має розумітися не як кінець злочинного людства, а як його перетворення на спільноти, солідарні в здійснюванному Духом піднесенні. Цей Дух своїм диханням несе й інші зміни, що мають статися й стануться в повторюваній грі трансляцій між фазами вичерпання й фазами поновлення. Зразковим прикладом тут $є$ контрастна ритмізація [scansion] між antiqui і moderni в VI столітті за Теодориха Великого, коли постала нагальна потреба відновити зв'язок із великою римською культурою, перерваний періодом безладдя (вторгнення, розгроми). Як забезпечити translatio studii, здатну 
відновити й надати новий імпульс згаслому чи зануреному в сон потенціалові культури, що відтепер стала стародавньою? Вимога трансляції, що з'являється тут, покликана повторюватися в перебігу історії, якій вона, втім, допомагає оприявнитися. Звідси можна вивести ідею активного симбіозу між обома термінами в тому альянсі, який вони укладаюють між неперервністю й перервністю. Та й чого варта непорушна і холодна темпоральність? Саме в таку трансляцію залучає нас перехід до Часів, що звуться Модерними (говорячи загалом, до XV і XVI століть), позначених, якщо вдатися до сильного формулювання Карлхайнца Штірле, «пануванням горизонтальної вісі трансляції над вертикальною» [Stierle, 1996: p. 55 sq.]. Тут ідеться про іншу манеру образно характеризувати Ренесанс, яскравим представником якого, згідно зі Штірле, був Петрарка - завдяки здатності «жити в двох різних світах і оспівувати цей досвід... Ренесанс $є$... відкриттям множинності, перспективи, поліфонії. Під культурою слід розуміти... культуру спілкування культур» [ibid.].

Що можна розуміти під «горизонтальною віссю»? Наголосимо тут лише на двох аспектах: передовсім на географічному вимірі, на відкритті нових земель і нових народів, які вражають наш світ і нашу культуру релятивністю. Про це велеліпно пише Монтень у розділі «Про засоби пересування» (Проби III, 6). Навівши місце 3 Лукреція (V, 331-334) «цей світ... ще новий, і не так то давно зародився» ${ }^{\text {vii }}$, він продовжує: «Наш світ відкрив ось другий світ (а хто нам ручиться, що це останній 3 його братів...), світ не менший розмірами, не менш плодючий і залюднений, ніж наш, а проте такий свіжий і дитинний, аж його треба допіру учити абетки... Якщо ми правильно міркуємо про наш кінець, а той поет - про молодість свого століття, то цей другий світ заледве вийде на світло, коли наш порине у пітьму, Всесвіт нібито спаралізує, один член буде закляклий, другий - кріпкий» viii [Montaigne, 1989: p. 886887]. Щоправда, на цю мить «наш» світ здійснює своє руйнівне панування, що спонукає тим більше шкодувати, що цей світ «не припав на Олександра або на стародавніх греків і римлян», що вплели б «грецькі та римські чесноти в природні чесноти цього краю» [порівн. зі Stierle, 1996] ${ }^{\text {ix }}$. У цих кількох рядках висловлено три ідеї: світ відкрився, зіставляючи (на добре чи на зле) краї та культури, позбавлені їхньої гегемонії.

Але горизонтальне у найвластивішому сенсі є тим, що стосується відносин між мовами, тих гравітаційних сил, що виникають довкола латини або супроти неї. Впродовж всього періоду, який прийнято називати «Середньовіччям», латина посідала третє місце, після гебрайської й грецької, таким чином, замикаючи вертикальну вісь канонічних мов одкровення й знання (причому останні розумілися як тісно пов'язані) й, окрім того, користаючись із давності й експансії Римського світу (себто римських Імперії й Церкви). Таким чином, трансляція відбувається «згори»«донизу», згідно з неоскаржуваним порядком стародавності. Оскарження постає в період Кватроченто, разом із появою на теренах Італії тих наріч [idiomes], що належали до Volgare, мовної єдності, яка протиставляла себе латині у вельми значущих відношеннях: йшлося про мови множинні, розмовні (не писемні), що поки не виробили стабільних форм, попервах призначені для поетичного ужитку; одне слово, позбавлені тих регалій, що складали достойність мови латинської. Але ось на захист Volgare стають гуманісти, як-от Леонардо Бруні й Спероне Спероні, що висунули головні аргументи: (1) всі мови, й латина теж, починали з того, що ними розмовляв народ, і лише згодом вони застигали у формах, освячених ученими ерудитами; (2) як продукти живої творчості, вони пройшли через фази дитинства й 
старості, щоби скаменіти в штучних формах, схилившись перед «мертвою буквою»; (3) тож усі вони рівні за своєю достойністю. Бруні вважав, що кожна мова має властиву їй досконалість і неповторний спосіб витонченого й наукового вираження [див. Baron, 1955: p. 305-306]. Але найпотужніші аргументи висловлено в «Il dialogo delle lingue» Спероні (1547), де стверджується, що мови всіх країн, як арабська, так індійська, як латинська, так і атенська, мають однакову цінність (siano d'un medesmo valore) i створені смертними шляхом однакового судження (con un giudicio formate) задля однакової мети. Спероні висновує з цього необхідність припинити марнувати найкращі молоді літа (відтак втрачувані для творчості) на сповнене складнощів вивчення якоїсь мови, що не слугує нашим сьогоденним потребам. «Але якщо би модерним вдалося колись створити для філософії й для науки мову, здатну досягнути кожної людини, модерна доба породила би тих Платонів і Аристотелів, що їх витворила доба стародавня» [див. Baron, 1955: p. 305]. Бенедетто Варкі продовжує цю думку: «Італійське народне наріччя $\epsilon$ мовою, що, порівняно 3 латиною, має розглядатися не як якесь псування, а як нове народження». Цей аргумент повторює Жоашен дю Беле у «Захисті й Прославленні французької мови» [див. ibid., p. 96-97].

Тут виникає ідея, якій судилося розвинутися за два-три століття по тому, ідея плідної сили мови для філософії, щільного переплетення тієї й другої. Складається враження, що ностальгія за Вавилонською вежею минула.

Ця перебудова стосунків між мовою й мисленням знаходить своє завершення й, певним чином, увінчання в тій гідності, яку індивід за собою визнає й собі завойовує. Зупинимося тут на такій показовій і багато в чому неоднозначній постаті, як Миколай Кузанський (1401-1463). Піднесений до сану кардинала, він мав усе, щоби постати у великій схоластичній традиції одним з Отців Церкви. Натомість він, хоч і писав латиною, присвятив себе прокладанню нових шляхів, вдаючись при цьому до стилю, що в свою чергу був новим. Але, як відзначає Ернст Касирер, він повинен був, мабуть, відмовитися від планів увійти в змагання 3 великими італійськими гуманістами. Однак латина Кузанця залишається дивною, невпорядкованою, помережаною оригінальними зворотами, що осяюють яснотою спекулятивні глибини тих великих засадових проблем, які вона несе в собі [Cassirer, 1983: p. 193]. В діалозі «Idiota de sapientia» виразником його позиції $\epsilon$ саме «Idiota» (близький за сенсом переклад: профан, освічений мирянин), що докоряє людям науки, науки поважної, опертої на авторитет і такої, що набувається тривалою книжною працею. «Профан» іронізує: ти нагадуєш «коня, вільного 3 природи, проте міцно прив'язаного за недоуздок до годівниці, з якої він їсть лише те, що йому дали» ${ }^{\mathrm{x}}$. Цей гострий діалог починається на ринковому майдані між «ученим» $\mathrm{i}$ «невігласом». «В який спосіб міг ти отримати знання свого незнання [Quomodo ductus esse potes ad scientiam ignorantiae tuae], якщо ти профан? - Не з твоїх, але з Божих книг. - Що то за книги? $\mathrm{Ti}$, що їх Він написав власним перстом. - Де вони знаходяться? - Скрізь. - Навіть на цьому майдані? - Звісно. Я вже казав, що мудрість волає “на вулицях".» Коментар Ханса Блюменберга прояснює цю ситуацію: невчений мирянин $є$ тут втіленням «читача книги світу», що здійснює «автономне мислення» в той спосіб, в який його здійснює раб у «Меноні». «Мирянин постає як протилежність витонченого професійного оратора гуманістичного штибу... книга світу явно написана в стилі, що не $\epsilon$ стилем риторики... яка символізує безплідну ерудицію» [Blumenberg, 2007: p. 41 sq.]. Мислення й живе слово винаходяться й упліднюються разом. 
Тріщина, що відкрилася таким чином, дістала на порозі сучасної епохи новий імпульс і розширення зусиллями Гердера й Гумбольдта. Втім, поки слід завершити сюжет з «профаном». В діалозі «Idiota de mente», пі продовженні розглянутого щойно діалогу «Idiota de sapientia», профан, наголошуючи на своїй ремісничій праці ложкаря, обстоює творчий аспект цього «мистецтва» хіi, оскільки воно є наслідуванням не природи, а «властивого Самому Богові ars infinita, в тому сенсі, в якому останнє постає як відпочаткове... Ложка $є .$. чимось абсолютно новим... а не попередньо даним природою. I простий “мирянин” є людиною, що іiї виробляє» [Blumenberg, 2000, p. 42]. Відлуння цих рядків за сто років по тому ми чуємо в славетному тексті Піко делла Мірандола «Про гідність людини», де Богові приписано такі слова: «Ані визначеного місця, ані власного обличчя, ані якогось осібного дару не даємо ми тобі, о Адаме, щоби й місце, й обличчя, й дари, які б ти обрав, ти за бажанням, за своїм рішенням [pro voto, pro tua sententia] мав у володінні... Нехай [наш] ум захоплює деяке священне прагнення, щоби ми, не вдовольняючись пересічним, палали найвищим... бо ми можемо, якщо воліємо [quando possumus si volumus]» ${ }^{\text {xiii }}$ [Pic de la Mirandole, 1993: p. 5, 13]. Такою була та нова тональність, яка прояснювала й навіть виправдовувала цей ренесансний термін, створений для того, щоби охарактеризувати прикметну зміну епохи.

В. - Але Вавилон - вавилонська зарозумілість - спроможна набувати нових проявів, що здатні, своєю чергою, виявитися стійкими. Той рух, що вивільнив «народні мови», надавши цінності їхній винахідницькій спроможності, виявився обмеженим і ніби зупиненим поверненням до зазіхань Сдиного. Пряме визнання цього знаходимо серед авторів «Граматики Пор-Роялю». Так, в Антуана Арно можемо прочитати: «найкращим засобом уникнути неясності слів, що зустрічаються в народній мові, $\epsilon$ створення нової мови» ${ }^{\text {xiv }}$ [див. Borst, 1995: S. 1284]. Це - П'ятидесятниця навпаки: повернення від множинності, оцінюваної як безладна, до єдино законної Сдності, гарантією якої є вдавання до потуги, вищої за будь-яку мову, відкриття «Cogito», яке зосереджує в певності «я» очевидність ясних і виразних ідей. Закликаний Мерсеном висловитися щодо «пропозиції нової мови», Декарт не відкидає з порогу цю ідею, проте вбачає ії складність у тому, «що було би легше зробити так, аби всі люди погодилися вивчити латину...» (АТ, t. I, р. 79: 24-26). Особливо ж слід би було встановити «деякий лад між усіма тими думками, що можуть увійти в людський ум» (p. 80: 24-26); бо «бо є такий [лад], природно встановлений між числами...» (р. 80: 26-27); і оскільки «винайдення такої мови залежить від істинної філософії» (p. 81: 910), то саме до неї слід приєднуватись. Це імпліцитно передбачає, що наука про числа й філософія звільняють нас від необхідності шукати в хащах слів ті єдині істинні блага, які вже маємо в розпорядженні, принаймні сподіваємося, що маємо. Насправді Декартові $є$ важливою сама лише «істинна філософія», утверджена прямим та інтуїтивним доступом до ідей, філософія, що влаштовує таке собі коротке замикання мови, зведення ii до стану простих мезозойських осадів. Проте Декартове дистанціювання від цієї «пропозиції» не завадило розпочати іiі втілення впродовж наступних десятиліть, коли намножувалися проекти «універсальної мови», створені «філософію, яка цементувала те, що доречно назвати «Просвітництвом».

Тут особливо виділяються, ба навіть впадають у вічі дві показові постаті. Передовсім Кондильяк. Його славетна праця «Проба щодо походження людських знань» (1746) містить виклад ретельної генеалогії безперервного піднесення тих операцій, що утворюють каркас людського мислення: від найперших форм (вигуки, жести) до найбільш опрацьованих виразів, вершиною яких постає алгебра. Від терміна до 
«Чи може національна фрілософрія бути точно визначеним дослідницьким об’єктом?»

терміна вибудовується неритмічна, проте безперервна генеза дедалі опрацьованіших мовних форм, аж до кінцевої стадії: «добре зроблена мова», що дорівнює найвищій досконалості рації. Тут йдеться немовби про якесь іманентне провидіння, етапи розгортання якого $є$ практично передвизначеними. Важкі початкові моменти крок за кроком ведуть до завершення, яке пояснить сенс кожного з етапів. Особливо значущим наслідком $є$ поступове усунення винаходу. «Ми воліли би переконати себе, що винахідники нічого не знайшли готовим, що вони все створили... [Однак] винайшли вони чи знайшли готовим лише те, що потрапило їм під руку... вони не покладалися на випадкове спостереження, вони аналізували... Ось і все, i це вже дещо» [Condillac, 1822: p. 179-180].

Але що таке це «дещо»? Воно не має нічого спільного з винайденням. Зовсім як «добре зроблена мова», що нею є алгебра. «Тут немає нічого довільного... Ужиток тут не має жодної влади... Всю витонченість стилю становить [тут] простота, адже істина мало відома народним мовам» [ibid., p. 5].

Виникають неуникненні запитання: що означає цей стиль без стилю? I що таке «говорити», якщо говориш як якась набірна алгебраїчна машина? В загальних рисах це та сама схема, яку пропонує Кондорсе у своєму останньому творі «Нарис історичної картини прогресу людського розуму» [Condorcet, 1970]. 3 тією лише різницею, що Кондильяк показує процес, який вже відбувається в людському суспільстві, процес, послідовні етапи якого він описує аж до тієї стадії, коли вони доходять свого повного здійснення, натомість Кондорсе вдається до прогнозування ще не реалізованого майбутнього, позначеного «встановленням універсальної мови». Остання також буде утворена зі знаків, що вказують на «прості й загальні ідеї». Тоді буде встановлено прямий доступ як до «теорії деякої науки», так і до «правил деякого мистецтва», що давало би людству змогу «день від дня поширюватися» та «слугувало би наданню всім об'єктам, які охоплює людський інтелект, тих суворості й точності, що роблять пізнання істини легким, а заблуду - майже неможливою» [ibid., p. 233-234]. Але це не $€$, уточнює Кондорсе, «химерною ідеєю». Ї̈ здійснення, таким чином, неминуче. Виробляючи цю мову, людство йде до відновлення мови, яка відтворить у майбутньому еквівалент мови початкової (Адам, Вавилон). Але тоді закрадаються два запитання: чому ця мова потребувала стільки часу для свого виникнення? I як розуміти це «майже» у зв'язку з заблудою? Або тут йдеться про кінець періоду, й тоді історію завершено, або ще залишається деяке поле для заблуд і нерішучості, й тоді відкривається майбутнє, сповнене несподіванок, якщо не повернень назад.

\section{Нове заснування вертикальної та горизонтальної осей у злитті універсального й одиничностей}

А. - Континент-океан: Ляйбніц (далі ми ще розглянемо цю метафору і пояснимо ii). Дуальність вертикальне/горизонтальне $є$ знаком напруги, внутрішньо властивої концептові «translatio», напруги між, з одного боку, гебрайською, грекою й латиною та, з другого, «місцевими» (природними) мовами, що виникають. Вона повторюється й зараз, у момент, який можна розглядати як епіцентр нашої проблеми: сповнений сум'яття перехід Ляйбніца до спричинених ним же наслідків, яких він безпосередньо не волів. Втім, сум'яття присутнє вже в самого Ляйбніца. Коли йдеться про останнього, то впадає у вічі та завдає клопоту коментаторам саме стала дуальність між двома течіями в мові, на позір цілковито супротивними одна одній: мовою «ідеографічною», 
формальною граматикою людської здатності розуміти, й мовами природними, сповненими розмаїття, неприборканими, такими, що принципово непідвладні обчисленню.

Відзначимо найпомітніші риси першої течії. Передовсім йдеться про вживані терміни. Залежно від ситуації, Ляйбніц каже про «characteristica universalis» або ж про «ars combinatoria». Останній термін походить від Раймунда Лулія, в якого є відповідником «ars Dei», комбінаторної або обчислювальної здатності Бога (відлуння цього знаходимо в Ляйбніца: «dum Deus calculat fit mundus [коли Бог обчислює, виникає

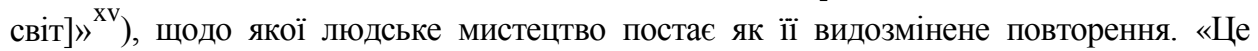
письмо було би різновидом загальної алгебри і надавало б засіб розмірковувати шляхом счислення. Тож замість дискутувати одне з одним, люди могли би сказати: обчислюймо. І виявилося б, що заблуди розмірковування - то лише заблуди обчислення, що так само, як і в арифметиці, відкриваються шляхом перевірки» ${ }^{\text {xi }}$ [Heinekamp, 1972: p. 462-463]. Це наголошує на виразній відмінності від природних мов, багатозначних у собі й розбіжних між собою. Отже, як показав Гайнекамп у висновку до другого свого тексту, написаного на ту ж тему [Heinekamp, 1975: S. 279], протилежність тут постає явною. Він підбиває підсумок: characteristica universalis $\epsilon$ instrumentum rationis, функції ж природних мов - численні й різноманітні. Перша $\epsilon$ «штучною системою» - у сенсі «мистецтва», - мистецтвом знаків, другі - системою знаків природних, себто таких, що не гарантують порядку між іменами й речами. Перша має молекулярну структуру, відповідну структурі однакового 3 нею порядку реальності, тоді як другі відповідають прагматичним інтересам. Першу засновано на суворому синтаксисі, другі ж мають несталий синтаксис, що оточує слова ореолом заблуди. Остання відмінність закріплює їхню протилежність: characteristica пропонує надійну статичну систему, тоді як природні мови презентують систему динамічну й відкриту. Цьому відповідає той факт, що перша презентується у формі, призначеній для письма, природні ж мови черпають свою силу у винахідницькому, сповненому пригод аспекті живого слова. Постає проблема: чи не $є$ ця протилежність остаточною й нездоланною? В такому випадку ми знову б отримали розрив між «вертикальним» (мова, що нисходить від рації) і «горизонтальним» (мови, розсіяні в «анархічний» спосіб).

Така контрастна ритмізація дуже швидко переходить на концепт «цифри/знаку» [caractère], що виявляється замкненим у межах однобічної (відтак - недостатньої) логіки, заданої деякими формулюваннями самого Ляйбніца: «Цифри $є$ певними речами, за допомоги яких виявляється вираженим стосунок між іншими об'єктами й користування якими є легшим за користування самими цими об'єктами» ${ }^{\text {xii }}$. Стосунок між речами, легкість користування: йдеться про прихований прагматизм, як можемо бачити 3 визначення, що фігурує у словнику 1733 р. («Під універсальним счисленням розуміється штучна процедура... що полягає у винайденні письма, символи [caractères] якого без вдавання до перекладу читалися й розумілися б усіма націями світу»; стаття «Character» 3 [Historisches Wörterbuch, 1971]). Але Ляйбніцева «дефініція» приховує те, про що тут йдеться, тобто власну здатність «вираження», яка не є стосунком речі до якоїсь іншої речі, а «унаочнює інтелектуальний доступ до істини об'єкта» [Kaulbach, 1966: S. 126]. Вона забезпечує переведення об'єкта в інший план, який рефлексивно відбиває його, перекладаючи тим у предмет, пристосований до концептуального схоплення. Провідною тут є метафора «дзеркала» (мова як дзеркало здатності розуміти). Але це дзеркало відіграє активну роль. Воно здійснює «рефлексивне відбивання» або відсвічування об'єкта, піднесеного до його здібності бути проектом розшифровки, яку здійснює здатність розуміти. Але ця 
здібність реалізується в будь-якій мові, наприклад, у мовах природних, хоча й у інших аспектах і супроводжуючись ефектами, що перевершують межі самої лише здатності розуміти, наприклад - у царині пасій і чуттів (affectus), як це демонструє поезія з іiі «прекрасними алегоріями чи зворушливими образами» (Лист до Бурге від 03.01.1714 ${ }^{\text {xviii }}$ [див. Heinekamp, 1972: p. 483]). Як дзеркало «дивовижного різноманіття операцій» (ума), мова не могла би бути зведена до простого викладення знань, вона ще й перекладає ті чуття й пасії, спричиненню яких сприяє. Чинячи це, мова дистанціюється від самого лише «счислення». Ця дистанція стає ще ширшою через факт «багатоманітності» мов, кожна з яких демонструє унікальний «відблиск». Тоді, на грунті архетипового засудження Вавилонського гріха, знову постає настирливе питання про буттєву підставу їхньої множинності. Ляйбніц показує себе тут, як і чимало інших мислителів від часів Ренесансу, рішучим прихильником «корисності й плідності». Якби людство розмовляло однією мовою, це означало б, що світ лишається таким самим, а людство не прогресує. «Початкова» мова, таким чином, повинна була (завдяки своїй природній мінливості) виявлятися в численних мовах i діалектах, кожен з яких виражає оригінальну точку погляду (про останню див. [ibid., p. 484]). Архетиповий початок обертається на актуальну початковість [originarité]. Звідси видно, що т.зв. протилежність між characteristica universalis і природними мовами набуває іншого сенсу. Між нею і останніми $є$ лише відмінність впливу: йдеться про структурування, з одного боку - унітарне й концентроване, 3 другого розділене та розсіяне. Вертикальне й горизонтальне увідповіднюються одне одному. Ось чому я ризикну вдатися до образу «континентальної» концентрації, з одного боку, та «океанічного» розсіяння, з другого. Втім, у кожному разі, тут завжди діє одна й та сама потуга відблиску.

Залишається ще третій аспект, поки не розглянутий. Природними мовами розмовляють, але не всіма одночасно. Серед них завжди $є$ одна привілейована, т.зв. «материнська» мова, себто та, яка «вивчається» в іманентному потоці особистого розвитку від народження індивіда. Тут ми торкаємося власної «долі» Ляйбніца: його стосунку до німецької - його ідіоматичної мови. Питання $є$ складним, амбівалентним [див. Belaval, 1976: p. 25-36]. Ляйбніц не пише німецькою, зробивши вибір на користь латинської та французької. Обирати ж німецьку йому доводиться лише щоби сказати похвальне слово про неї. Так, в одному з рідкісних текстів, написаних цією мовою («Заклик до німців вправлятися в їхній здатності розуміти та в їхній мові», датується, ймовірно, 1682-1683 рр.), наштовхуємося на похвальне слово «одному доброму, поважному й старому німцеві [ein guther ehrlicher alter teutscher]» (не названому прямо, однак йдеться, ясна річ, про Якоба Бьоме), в якого «все було влаштоване $з$ такими яснотою, силою й, водночас, природністю, що я не міг завадити собі засумніватися, чи спромігся б досягти того ж». А це відсилає до вирішальної передумови: «всі історики згодні між собою, коли кажуть, що нація і мова процвітали в один і той самий час, що греки й римляни пізнали свою найвищу потугу в мить, коли серед перших жив Демосфен, а серед других - Цицерон...». Звідси випливає, що «ліпше бути німецьким оригіналом, ніж французькою копією» ${ }^{\text {xix }}$. I все ж Ляйбніц тримався за латину, мову конфірмованого кліру, і за французьку, мову освічених порядних людей, що була тоді загальноєвропейською. В теоретичному плані лишається деяка трирівнева гра концентрації і децентрації, що зайшла вельми далеко: в центрі - максимальна децентрація («природні» мови), облямована концентрацією, як згори (проект універсального счислення, безперервно поновлюваний і позбавлений кінця-краю), так і знизу - 
інтенсивне одиничне індивідуальної говірки; усі разом постають як концертна симфонія, яку виражає ідея «монадології»: «узгодженість усіх сотворених речей з кожною, і кожної - з усіма іншими, дозволяє кожній простій субстанції мати відношення, що виражають усі інші [прості субстанції], і... вона $\epsilon$ постійним живим дзеркалом всесвіту» (Монадологія, § 56) ${ }^{\mathrm{xx}}$. В одиничних варіаціях єдиний Всесвіт розділяється на множину версій і повторює себе.

В. - В спадщину від Ляйбніца - умовно кажучи - залишилася ідея деякого vinculum linguarum $^{\text {xxi }}$, що очікувала на подальший розвиток, який не забарився. Потреба у ній виявляє себе в Гердерових «Ідеях стосовно філософії історії людства» (1784-1791): «Позаяк я не можу навести тут якоїсь праці, де фізіогномія націй була б досліджена на основі їхньої мови... таким чином, щоби була створена... найкраща логіка та найкраща метафізика здатності розуміти [Verstandes]... має з'явитися новий Ляйбніц, коли прийде його час» (кн. 9, розд. 2) ${ }^{\text {хіiі }}$. Власне, естафету підхоплять двоє: Гердер і Гумбольдт. Почнеться все з Гердерової морської подорожі у Францію (1769 рік). Віддаленість від порту приписки (Рига) й самотність серед моря спонукали його поставити під радикальне запитання тодішню європейську культуру, 3 якого випливає обов'язок в один чудовий день порвати з абстрактністю й знеосібленістю модерної цивілізації, символом якої є «Енциклопедія» («...ця книга... в якій французи вбачають свій тріумф, є для мене найпершою ознакою їхнього підупадання... Оригінальні праці зникають» [цит. за Blumenberg, 2007: р. 182]. Постає термінова потреба заснувати пов'язану з рештою світу національну літературу, примножуючи розриви й точки погляду без ізоляціонізму й упередженості («...новий світ мов... народів... Погляд відкриває немовби безкраїй океан нових націй». В серці такого задуму накидає себе Мова й водночас випромінюються мови в їхній безмежній проліферації. Кожен з цих двох моментів має свій власний нервовий центр. У випадку більшості мов він знаходиться в компаративному дослідженні різноманітних типів вираження, бо «бо геній народу ні в чому не відкривається з більшою очевидністю, ніж у фізіогномії його мови» ${ }^{\text {xiii }}$ [ibid.]. Гердер лише накреслив ту програму, яку перейняв і розширив Гумбольдт. Саме в останнього ми зустрічаємо найгрунтовніший ii розвиток. Стосовно ж «Мови», то вирішальний елемент було вироблено в трактаті, де обговорюється іï̈ «початок» (Abhandlung über den Ursprung der Sprache). Однак цей початок - це сама мова, обидва терміни становлять одне ціле. Її початок не приходить до неї невідомо звідки. Вона у самій собі є своїм початком, це «початковий стрибок», що воднораз повертає від тваринності до людськості. В цьому «воднораз» відлунює Ляйбніцева «Монадологія»: «монади могли би започаткуватися і припинитися не інакше як ураз» (§ 6). Вівця являє себе; я іії сприймаю. Проте сприймати - це реагувати, відповідати зустрічним ударом, що запускає в дію такий собі різновид внутрішнього ремигання [rumination], передаваний терміном Besonnenheit (діяльність рефлексування [activité réfléchissante]) ${ }^{\text {xiv }}$. «Той, хто рефлексує», стає людиною в тій мірі, в якій він може «sich in sich bespiegeln [відображати себе в собі]», спричиняти в собі свій власний відблиск, таким чином наділяючи плоттю «внутрішнє дзеркало», про яке казав Ляйбніц, але цього разу - за свій рахунок і на свій ризик, у проліферації звуків, що стають словами. Мова існує лише у винайденні, імпровізованому, не переглянутому якоюсь вищою інстанцією, як-от «рація» філософів. Й справді, останні «розмовляють як боги», підносячись над реальними умовами формування концептів, тобто - над переплетіннями мови. Це слово «мова» $є$ ще й надто абстрактним. Потрібно завжди 
повертатися до звичайної мови, зануреної в життя народу, що призводить до перегляду успадкованих моделей. «Що таке мислити? [Це означає] вести внутрішню розмову» [Herder, 1960: S. 180]. Й відтоді «метафізика стає філософією людської мови» [ibid., S. 184], радикально далекою від мови богів чи ангелів, тієї, якою мовлять у школах чи 3 кафедр. Вся плідна творчість Гердера, нерозривно пов'язана 3 його життям, $\epsilon$ невпинним повторенням цієї субверсивної ідеї в нескінченному розмаїтті їі модуляцій.

Хоча й іншими, проте виразно аналогічними шляхами Вільгельм фон Гумбольдт береться за таким чином сформульоване завдання [див. Caussat, 2012]. Його стартовим пунктом є розрив із «сенсуалістськими» схемами, успадкованими від Просвітництва, зокрема від Кондильяка, праці якого були ним уважно прочитані під час перебування в Парижі (1797-1799). Кондильяк має деякі заслуги: «Він ганить вроджені ідеї» [див. Caussat, 2004: p. 58 ], себто те, що становить основу інтелектуалістських метафізик, але тільки для того, щоби одразу ж переключити напрям, перейшовши від «аналізи» до постулату побудови ідей у безперевному поступальному рухові від елементарних відчуттів. «Він хоче виміряти межі здатності розуміти, визначити ії операції, прослідкувати формування ідей, але жоднісінього разу не сягає їхнього справжнього формування» [див. ibid., p. 56]. Останнє ж невіддільне від природної мови, хай би навіть і «варварської», як-от баскська мова, яку Гумбольдт відкрив одразу по тому, як 1800 року прибув до Іспанії. Отже, він побачив, що там існує народ, який розуміє самого себе, водночас розуміючи довколишній світ, на основі узгодженої гри тісно пов'язаних одне з одним звуків та ідей. Це відкриття невдовзі зумовило той поворот, який визначав усе життя Гумбольдта аж до його смерті в 1835 році. Тридцять п’ять років він невтомно перебував у гонитві за мовою з усією множинністю ії територій і актуалізацій (лексичних і семантичних). Початок цього шляху - розрив як із Ляйбніцем, так i з Кондильяком: мова «не є ансамблем ані концептуальних, ані випадково залучених в ужиток знаків, в якому слово не має іншої детермінації й сили, ніж та, що воно нагадує про певний об'єкт поза ним, чи то присутній у реальності, чи то мислимий в умі, [й щодо якого ми визнаємо], що для пізнавальної практики байдуже, яку мову уживає та чи та нація...» [див. Caussat, 2012: p. 203]. Тут він приєднується до Гердера: мова, ця жива тканина, що зв'язує людських суб'єктів у їхньому зусиллі зрозуміти себе поміж інших і зрозуміти світ, «відтак є... засобом, за допомоги якого людина обробляє себе, водночас піддаючи обробіткові світ, або ...за допомоги якого вона стає самосвідомою саме в тому, що розташовує світ поза собою» [див. ibid., p. 204]. Це ілюструється славетною «аксіомою»: «мова $\epsilon$ органом, який уформовує (bildet) мислення» [Humboldt, 1963: S. 426], подібно до того, як рух смичка по струнах скрипки уформовує мелодію. 3 цупкої тканини гумбольдтівського починання у майбутньому збережеться передовсім така яскраво виражена, поза сумнівом, риса його дискурсу, як оперування парами термінів, що є водночас протилежними і взаємодоповнювальними.

Наприклад, зміст/обсяг. Для узвичаєної докси ці терміни є протилежними (що глибший зміст поняття, то вужчий його обсяг). Але в Гумбольдта вони діють спільно: безмежне збільшення кількості мов відкриває неозоре поле осередків слова, кожен 3 яких актуалізує одну й ту саму здатність винаходити. Маємо таке собі перевертання відомої приказки: порівняння спричиняє роботу рації ${ }^{\mathrm{xx}}$. Те саме й у випадку пари згода/незгода. Мова живе в міжособистісному стосункові суб'єктів, що розмовляють (пара «запит/відповідь»), а відтак «ніхто у слові не мислить точно ту саму річ, що й інший... Ось чому будь-яке розуміння водночас $є$ нерозумінням, будь-яка згода в думках і чуттях є водночас розбіжністю» [див. ibid., S. 439]. Tе саме 


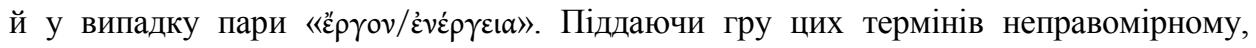
мабуть, примусові, в «єُрүоv» вбачатимуть упорядковану структуру, що перебуває в

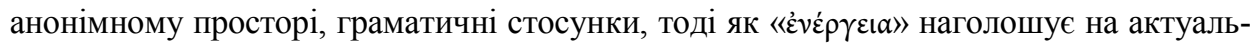
ній потузі слова в його творчих вібраціях (певним чином ця ситуація постає як непрямий еквівалент «счислення», протилежного вібруванню природної мови).

Залишається узяти до розгляду останню пару, яка приведе нас до головного джерела гумбольдтівського дискурсу: розрізнення (Verschiedenheit)/зрівнювання [égalisation] (Vergleichung постає як буквальна транспозиція «порівняння»). Інакше кажучи, відмінність/тотожність. Йдеться про пару, пов'язану 3 парадоксом: мови є рівновартісними, рівними на підставі їхньої розбіжності. Переходячи до пари, що лежить в основі цих термінів, ми сягаємо архетипової дуальності: одиничне/універсальне. Щоби оцінити іiі сенс, слід повернутися в передляйбніцеві часи, до Миколая Кузанського, де вона відіграє вирішальну роль, яку можна пояснити, добудувавши іiі до тричастинного комплексу complicatio/ explicatio/ concretio. Кожна «конкретна» реальність вбудовується в неозоре відкрите поле між «заплутаністю» (сукупність всього) і «поясненням» (широким розсіянням, відкритим нескінченності), індивідуальну контрастну ритмізацію якого вона позначає. Остання визначається стосунком, який вона підтримує 3 «принципом» (універсальним, Абсолютом), джерелом цієї сукупності, й іншими контрастними ритмізаціями (індивідами), що населяють поле, яке розділяє дві його межі-облямування. Якою тоді є організація цієї «системи»? Абсолютна тотожність (Принцип) з яснотою виражає себе в полі несхожостей, що вимагають (отримуючи своє буття від Принципу) своєї власної тотожності перед лицем суміжних тотожностей, позначених відмінністю. Таким чином конституюється мережа тотожностей, кожна з яких, зберігаючи упричетненість початковій тотожності, водночас потребує створення деякого засадово диференційного середовища. «Отпе quod est, est idem sibi ipsi et alteri aliud» (Миколай Кузанський, De Genesi ${ }^{\text {хxvi }}$; цит. за [Leinkauf, 1999: p. 145]). У Всесвіті, вважає Кузанець, кожне одиничне суще є, висловлюючись відносно, абсолютом. Тотожне лише собі, воно є іншим абсолютом стосовно будь-якої іншості іншого. Ця тотожність, відрізняючись від абсолютної тотожності Принципу (Бога), є тоді тотожністю у відмінності й через відмінність [за текстами, цит. у Beierwaltes, 1980 i Leinkauf, 1993]. Всесвіт, таким чином, є мережею перехресть тотожності й відмінності, що утворюються взаємоузгоджено. Перенесемо цей висновок на Всесвіт мов. Принцип (Мова, що розуміється тут як мовний потенціал) робить 3 кожної існуючої мови деякий активний одиничний центр, незвідний до усіх інших, а також пов'язує його $з$ ними через диференційовану причетність до універсальної мовної гри. Урівнює мови саме їхня завжди одинична винахідницька потуга, відкрита

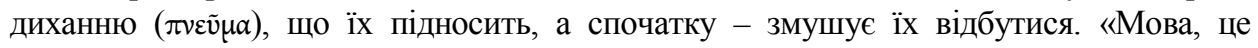
непоясненне диво, виникає в вустах деякої нації». Гумбольдт каже це 3 приводу басків,

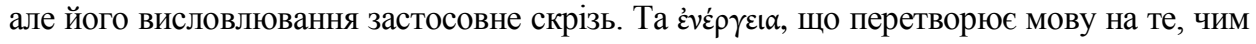
остання стає, може прийти як раптове виверження, миттєве, не передбачене, в якому окреслюються неочікувані спочатку й безперервно продовжувані горизонти, продовжувані на всіх рівнях, що будуть відкриті згодом, постфактум, позаяк вони залежать від поезії, літератури чи, звісно ж, філософії. Остання тоді має вигляд знову низведеної - з небес Ідеї до викликів землі, до вимог людей, втілених у якійсь нації, що несе їх і, у певному сенсі, на них очікує та породжує їх. Проте філософія стикається 3 великим викликом: вона має обирати між двома шляхами: шляхом усамітненого мислення «філософа», що, піднісшись у вишину, розмірковує наче якийсь бог (пред- 
мет Гердерового сарказму), або ж - шляхом мислення втіленого, імплантованого в живе ціле нації, яка його несе, і мови, яка його зрошує. Зрозуміло, що Гумбольдт бачить у філософському діалозі найживіше і найдимічніше вираження втіленого мислення, в якому ідеї винаходяться шляхом протистояння з партнерами по вільному пошукові, не потребуючи трансцендентного одкровення. Логос, що шукає і розгортає себе в цьому, розірвав зв'язки із чарами того Сдиного, яке надає сил і огортає, але ціною відмови від свого я в його застиглому Ладі.

Завершальні зауваги. - Ляйбніц інколи апелює до деякої philosophia perennis: такої собі єдиної Мудрості, що була від початку й у різних формах, але безперервно продовжується з віку в вік. Що це, втішна ностальгія? Невже історію згодом занесло десь на повороті, що вона узялася виробляти одиничні (неузгоджені?) відмінності, як їх описує Габріель Тард: «...мабуть, найменш неправильною класифікацією є та, що спирається на відмінність національностей, себто - природ національного духу, від яких вони походять. Бо, певна річ, є лінія французьких філософів, інша - філософів англійських, ще інша - німецького стилю, й кожна 3 них характеризується вельми різними якостями» [Tarde, 2002: р. 258]. Але це твердження не є показовим. Натомість істотний сенс слід шукати у переписуванні «Монадології» (див. вперше видану 1893 р. працю «Монадологія і соціологія», сучасне перевидання [Tarde, 1999]), в якому Тард, наважившись створити другу «Монадологію», ставить під знак запитання схильність філософів переоцінювати тотожність, аби згодом штучно утворювати з неї різноманіття. Ось де криється чіпкий передсуд, який слід піддати розглядові. «Існувати - це відрізнятися... Відмінність $є$ альфа й омега Всесвіту... Що може народитися від шлюбу монотонного й гомогенного, окрім нудьги? Коли все походить від тотожності, а також націлене на неї та йде до неї, що є джерелом цього потоку розмаїття, який так захоплює нас? ...Типи лише гальмують» [Tarde, 1999: p. 72-80]. Супроти цього одразу ж окреслюється «віще» заперечення: якщо все $є$ різним, все є відносним: релятивізм. Ось, таки промовлене велике слово! Натомість Тард, розвиваючи дотичні дискурси Ляйбніца й Миколи Кузанського, виразно обирає бік реляціональності [relationalité] ${ }^{\mathrm{xxvii}}$. Це - один із сенсів спільного для них «перспективізму», шлях якого теж відкриває Кузанець: світ є єдиною мережею, в якій кожне одиничне (стягнене [contracté]) імпліцитно включає тотальність усіх інших, жодним чином не становлячи частини цих інших. Таким чином кожна річ $є$ по-своєму нескінченною, не розриваючи свого зв'язку з іншою. Звідси випливає, що не може бути точної рівності між двома речами, кожна з яких зберігає свою відмінність. Перспективізм вказує на той спосіб, в який одне суще може утверджуватися саме, не ізолюючись від інших, не припиняючи залежати від мережі, заснованої абсолютною єдністю (див [Воehm, 1969: S. 137]).

Через це виявляється підсиленою закоріненість у «горизонтальному». Бо припиняється опікування Принципу (Бога, Буття, Сдиного, Логосу) уярмленими і підлеглими (стягненими [contractés]) сущими. Разом із мовою розв'язує свої пута й субординація, ба вона навіть зникає цілковито. Адже мова містить лише пульсацію слів, що сплітаються й відриваються одне від одного в просторі деякої повнощедрості, що ніколи не улягає суворому контролеві, хіба що у випадку тоталітарного загарбання, нещодавній досвід якого показує, що йому завжди бракує сили задля встановлення абсолютної німотності.

Настав час зробити висновок. «Національна філософія» - це об’єкт дослідження? Так, як одинична й неочікувана варіація усередині деякої тенденції, що лише для 
байдужого й віддаленого погляду здається безперервною. А чи є вона «точно визначеним об'єктом»? Ні, причому з двох підстав: (1) цей «об'єкт» $є$ передовсім «суб'єктом», осередком винайдення, здійснюваного на основі радикальної контингентності, осередком живим, багатоманітним, водночас розкольницьким і засадовим. «Джерело заколотів $\epsilon$ водночас джерелом відновлення» [Tarde, 1999: p. 81]. I (2), цей суб'єкт відкривається як минулому, від якого він відривається в своєму раптовому, неймовірному виникненні, так і наперед не детермінованому призначенню, не маючи точно встановленої межі в океані можливостей, надійний підрахунок яких неможливий.

\section{ПРИМІТКИ ПЕРЕКЛАДАЧА}

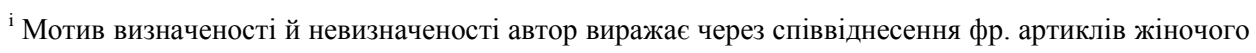
роду: визначеного (la) і невизначеного (une).

iі Цитату з Плотіна перекладено за французьким перекладом, яким послуговувався автор статті. В

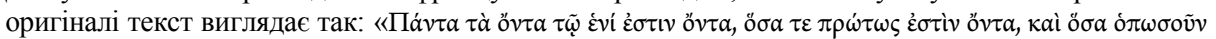

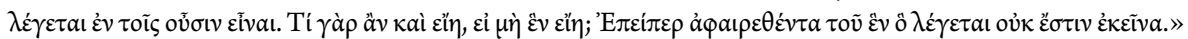

iii Цитату з Плотіна перекладено за французьким перекладом, яким послуговувався автор статті.

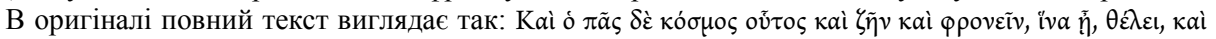

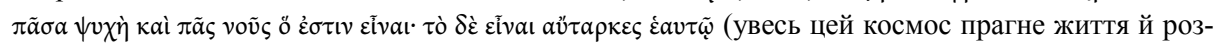
важливості, щоби бути; всі душі й усі уми прагнуть цього; буття ж є самодостатнім).

iv Цитату з Прокла перекладено за французьким перекладом, яким послуговувався автор статті. Букв. переклад гр. тексту: «Будь-яка множина є вторинною щодо єдиного».

v Тут і далі цитування Біблії українською здійснюється за перекладом І. Хоменка.

vi Гра слів: у фр. мові слово sujet означає і «суб'єкт», зокрема й у значенні самостійного центру активності, й також «підданий», «підлеглий».

vii Текст наведено за перекладом Андрія Содомори, відтвореним у виданні Монтень М. Проби. Книга III. - Київ: Дух і літера, 2007. - С. 136.

viii Текст наведено за перекладом Анатоля Перепаді зі змінами (Монтень М. Проби. Книга III..., 2007. - С. 136-137).

ix Текст наведено за перекладом Анатоля Перепаді (Монтень М. Проби. Книга III..., 2007. - С. 138).

х Текст Кузанця при перекладі з фр. перекладу тут і далі зіставляється за оригінальною електронною версією, розміщеною на сайті Cusanus Portal. Режим доступу: http://urts99.unitrier.de/cusanus/content/werke.php?werk=29

${ }^{x i}$ Ел. версію тексту цього діалогу див. на ресурсі, вказаному в попередній прим.

хіi Гра слів: у латині слово ars означає водночас і «ремесло», і «мистецтво». Різниця цих слів в українській мові чітко вказує на дистанцію між буденним і піднесеним, натомість у латині ці аспекти закріплені за однією лексичною одиницею.

хіiі Текст французького перекладу зіставлено з латинським оригіналом за виданням: Pico della Mirandola G. Oratio de Hominis Dignitate: Oration on the Dignity of Man / English Translation by Elizabet Livermore Forbes. - Lexington, Ky: Anvil Press, 1953. - P. 7.

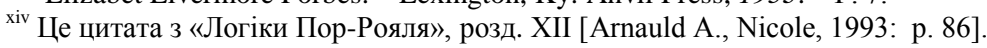

${ }^{\mathrm{xv}}$ Leibniz G.W. Dialogus // Leibniz G.W. Die philosophischen Schriften, Bd. VII / hrsg. C.I. Gerhardt. Berlin: Weidmann, 1890. - S. 191. (Nachdruck: Hildesheim, New York: Georg Olms Verlag, 1978).

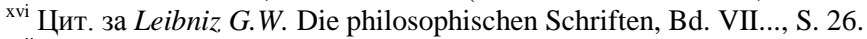

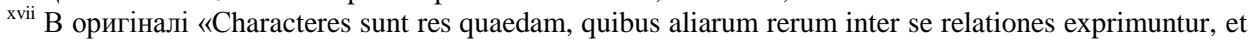
quarum facilior est quam iliarum tractatio» (Leibniz G.W. Characteristica geometrica // Leibnizens mathematische schriften, Bd. V / hrsg. C.I. Gerhardt. - Berlin, A. Asher, 1858. - S. 141.

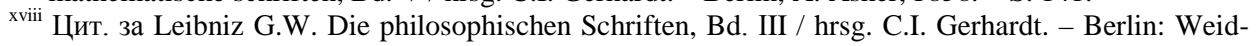
mann, 1890. - S. 562.

хіх Цитовані тексти перекладено з фр. перекладу. Зіставлення з нім. оригіналом здійснювалося за виданням Leibniz G.W. Ermahnung an die Teutsche, ihren verstand und spräche beßer zu üben // Leibniz G.W. Sämtliche Schriften und Briefe, 4. Reihe: Politische Schriften. - Berlin: AkademieVerlag, 1986. - Bd. III. - S. 814-815. 
хx Український переклад цит. за виданням Ляйбніц Г. В. Монадологія / переклад П. Бартусяка під редакцією О. Хоми. - Sententiae. - vol. XXVIII. - 2013. - № 1. - С. 167.

ххі «Мовного зв'язку» (лат.).

xхіi Цитовані тексти перекладено 3 фр. перекладу. Зіставлення з нім. оригіналом здійснювалося за виданням Herder J.G. Ideen zur philosophie der geschichte der menscheit / hrsg. von Eugen Kühnemann // Herder J.G. Herders Werke: Teil 4, Abt. 2. - Stuttgart: Union Deutsche Verlagsgesellschaft, [ca 1885/1894]. - S. 339-340.

xxiii Ibid., S. 339.

xxiv Автор цитує Гердера, який розглядає формування суто людського сприйняття на прикладі сприйняття образу вівці: «Da ist z. E. das Schaf... Aber horch! das Schaf blöket!...» (Abhandlung über den Ursprung der Sprache Erster Teil, Dritter Abschnitt, 1. Töne). - Усталені значення нім. Besonnenheit - розсудливість; вдумливість; обережність.

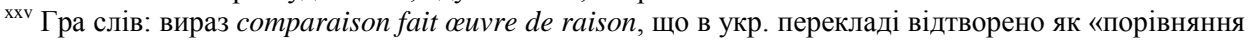
спричиняє роботу рації», $є$ парафразом відомої приказки comparaison n'est pas raison (порівняння - не доказ). Важливо відзначити, що слово raison в кожному з цих випадків набуває різних укр. відповідників.

xxvi «Bce, що $\epsilon, \epsilon$ тим самим для себе самого й іншим для іншого» (лат.). - Оригінал див. Cusanus Portal. Режим доступу: http://urts99.uni-trier.de/cusanus/content/werke.php?werk =29

хxvii Поняття сучасної філософії, покликане відобразити істотність стосунків 3 іншими для існування речі, в певному сенсі - протилежність «субстанції» як самодостатнього буття. $€$ ознакою більш діалектичного розгляду єдності як мережі стосунків між окремішностями.

Постає синонімом англ. relatedness передовсім у сенсі зв'язаності стосунками. Наприклад, А. Н. Вайтхед вважав, що всяке «значення» - не що інше, як схоплення реляціональності речей («"Significance” is the relatedness of things»), себто «речей у їхніх стосунках й остільки, оскільки вони перебувають у стосунках (of things in their relations and as related)» (Whitehead A. N. An Enquiry concerning the Principles of Natural Knowledge. - Cambridge: Cambridge UP, 1919. - p. 12). Нині в англ. мові вживається також термін relationality (почасти синонім relatedness), що теж вказує на стан того, що зумовлене стосунками (relational).

Поняття $€$ поширеним в контекстах фундаментальної онтології (нерозривна пов'язаність людського буття зі світом: див., наприклад, Roth W.-M., More D. Énaction. Apprendre et enseigner en situation. - Bruxelles : De Boeck, 2008. - P. 59-60) та теології (нерозривна пов'язаність і диференційованість між Особами Трійці: див., наприклад, Bondo G. Analogie de l'avent: Transcendance de l'extériorité et critique anthropologique. - Paris : Harmattan, 2010. - p. 156). Варто відзначити, що relatedness i relationality належать до термінології комп'ютерних наук, вказуючи на пов'язаність елементів у базах даних.

\section{СПИСОК ЛІТЕРАТУРИ}

Arnauld A., Nicole P. La logique, ou L'Art de penser: contenant, outre les règles communes, plusieurs observations nouvelles, propres à former le jugement / éd. critique par P. Clair et F. Girbal. - Paris : Vrin, $1993^{2}$.

Assmann A. The Curse and Blessing of Babel, or Looking Back on Univer salisms // The Translatability of Cultures: Figurations of the Space Between / ed. by S. Budick and W. Iser. Stanford, Calif.: Stanford UP, 1996. - P. 85-100.

Sancti Augustini opera: Enarrationes in Psalmos 51-100; pars 1. Enarrationes in Psalmos 51-60 / Hrsg.. H. Müller. - Wien: Verl. der Österreichischen Akad. der Wiss., 2004.

Baron H. The Crisis of the early Italian Renaissance. - Princeton, N.J.: Princeton UP, 1955. - T.1.

Beierwaltes W. Denken des Einen. - Frakfurt a. M: V. Klostermann, 1985.

Beierwaltes W. Identität und Differenz. - Frankfurt a. M: V. Klostermann, 1980.

Beierwaltes W. Platonisme et Idéalisme / tr. par M.-Ch. Challiol-Gillet, J.-F. Courtine, P. David. Paris: Vrin, 2000.

Belaval Y. Leibniz et la langue allemande // Belaval Y. Études leibniziennes: de Leibniz à Hegel. Paris: Gallimard, 1976. - P. 25-36. 
Blumenberg $H$. L'imitation de la nature et autres essais d'esthétique / tr. par I. Kalinowski, M. de Launay. - Paris: Hermann, 2010.

Blumenberg H. La lisibilité du monde / tr. par P. Rusch, D. Trierweiler. - Paris: Cerf, 2007.

Boehm G. Studien zur Perspektivität. - Heidelberg: C. Winter, 1969.

Borst A. Der Turmbau von Babel / Umbau. 1. - München: Deutscher Taschenbuch Verlag, 1995. S. 956-1394.

Cassirer E. Individu et Cosmos dans la philosophie de la Renaissancet / tr. fr. - Paris: Ed. de Minuit, 1983.

Caussat $P$. La confrontation entre Analyse et Synthèse: Humboldt avocat de la révolution kantienne face à la pensée héritée de Condillac // Kodikas/Code. Ars Semeiotica. - Band 27. - 2004. - Heft 1/2; Special Issue/Themenheft: Sprachdenken zwischen Berlin und Paris: Wilhelm von Humboldt = La pensée linguistique entre Berlin et Paris: Wilhelm von Humboldt / Hrsg. Sarah Bösch \& Markus Meßling. - Tübingen: Günter Narr Verlag. - S. 51-64.

Caussat P. Crise de la raison-Logos et invention de la raison-langue // Sofia E., Normand C. Espaces théoriques du langage : des parallèles floues. - Louvain-la-Neuve: Academia, Louvain-laNeuve: Academia; Paris: Harmattan, 2012. - P. 187-222.

Condillac, E. Bonot de La langue des calculs // Condillac, E. Bonot de Oeuvres Complètes in 16 vol. - Paris: Lecointe et Durey, 1822. - v. 16.

Condorcet, J.-A. N. de, Marquis de Caritat Esquisse d'un tableau historique des progrès de l'esprit humain / présentée par Y. Belaval. - Paris: Vrin, 1970.

Danielou J. Origène. - Paris: Ed. du Cerf, 2012².

Descartes R. Euvres / Ch. Adam et P.Tannery. - Paris: Vrin, 1996. - t. I.

Heinekamp A. Ars characteristica und natürliche Sprachen bei Leibniz // Tijdscrift voor Filosofie, - 34ste Jaargang. $-\mathrm{n}^{\circ}$ 3. -1972 . - P. 446-488.

Heinekamp A. Natürliche Sprachen und Allgemeine Characteristik // Studia Leibniziana, Supplementa 15: Akten des $2^{\circ}$ internationalen Leibniz-Kongresses, 1975. - S. 257-286.

Herder J.-G. Idées sur la philosophie de l'histoire de l'humanité / tr. E. Quinet; introd/, notes et doss. par M. Crépon. - Paris: Presses Pocket, 1991.

Herder J.-G. Sprachphilosophische Schriften / mit einer Einleitung, Anmerkungen und Registern Versehen von E. Heintel. - Hamburg: Meiner, 1960.

Humboldt $W$. von Über die Verschiedenheit des menschlichen Sprachbaues und ihren Einfluss auf die geistige Entwicklung des Menschengeschlechts // Humboldt W. Werke in fünf Bänden; 3. Schriften zur Sprachphilosophie / Hrsg von A. Flitner und K. Giel. - Stuttgart: J. G. Cotta, 1963.

Ivanka E. Von. Plato Christianus / trad. par E. Kessler ; révisé par R. Brague et J.-Y. Lacoste Paris: PUF, 1990.

Kaulbach F. Der Begriff des Charakters in der Philosophie von Leibniz // Kant-Studien. - 1966. № 5. - S. 126-141.

Leibniz G.W. Exhortation adressée aux Allemands / tr. fr P. Caussat // La langue source de la nation: messianismes séculiers en Europe centrale et orientale du XVIIIe au XXe siècle. Liège: Mardaga, 1996. - P. 45-66.

Leibniz G.W. Monadologie. - Paris: Librairie générale, 1991.

Leinkauf T. Mundus Combinatus: Studien zur Struktur der barocken Universalwissenschaft am Beispiel Athanasius Kirchers SJ (1602-1680). - Berlin: Akademie Verlag, 1999.

Mirandole, J. Pic de la De la dignité de l’homme / trad. du latin et préf. par Yves Hersant // Mirandole, J. Pic de la CEuvres philosophiques. - Paris: PUF, 1993.

Montaigne M. Essais (l. 3,ch. 6 «Des coches»). - Paris: Gallimard, 1989. - Coll. «Bibliothèque de la Pléiade».

Nicolas de Cues La sagesse, l'esprit, les expériences de statique selon l'idiot = Idiota de sapientia, de mente, de staticis experimentis / trad. de F. Coursaget, introd. et comm. de R. Bruyeron. Paris: Hermann, 2012.

Plotin Ennéades. - Paris: Les Belles Lettres, 1954. 
Proclus Théologie platonicienne. - Paris: Les Belles Lettres, 1964.

Speroni S. Dialogue des langues / trad. de C. Gruget, - Paris: Jean Longis, 1551.

Stierle K.H. Translatio Studii and Renaissance: From Vertical to Horizontal Translation // Translatability of Cultures. Figurations of the Space Between / ed. by S. Budick und W. Iser. Stanford, Calif.: Stanford UP, 1996. - P. 55-67.

Tarde G. Monadologie et Sociologie // Oeuvres de Gabriel Tarde; $1^{\circ}$ série, vol. $1 /$ présent. d'É. Alliez; postf. de M. Lazzarato. - Le Plessis-Robinson: Institut Synthélabo pour le Progrès de la Connaissance, 1999.- Coll. «Les empêcheurs de penser en rond».

Tarde G. Philosophie de l'histoire et science sociale: la philosophie de Cournot / éd et présentation Th. Martin // Oeuvres de Gabriel Tarde; $2^{\circ}$ série, vol. 4. - Paris: les Empêcheurs de penser en rond: [diff.] le Seuil, 2002.

Стаття одержана редакцією 05.03.2014

\section{Pierre Caussat}

\section{«Could "national philosophy” be strictly defined research object?» Ebb and flow between the unit (common) and multiple (differential)}

The word and idea of a «national philosophy» come up against a seemingly insurmountable aporia between the demand for a universal wisdom (philosophia perennis) and the need to incarnate this pursuit in the manifold and varied cultures.

This aporia is mythically revealed in the conflict between the unified, solid, senseless language of Babel and its redemption in the shared understanding by different peoples and idioms (Pentecost).

This myth finds its effective incarnation in the multiplicity of human cultures along human history. But this history is marked by a double conflict:

- a symbolic one in the competition between a «vertical» order (the rule of languages considered to be sacred) and a «horizontal» order challenged by the outcome of new secular idioms (Volgare in Italy of Renaissance);

- a polemical one in the recurrence of the tension between the building of a «lingua universalis» (a logical one) and the fertility of «natural» idioms. (at the epicenter of this tension radiates thought of Leibniz).

What emerges from these oppositions is the part played by language, in the diversity of its expressions. This diversity enables the emergence of a «nationalization» of philosophy. From then on, it seeks and coins itself in the midst of fundamentally peculiar cultures (nations) competing in an inventive, contrasting and vulnerable quest for meaning.

Pierre Caussat, famous French philosopher, linguist, translator, former professor of philosophy at Paris West University Nanterre La Défense

П'єр Коса, відомий франиузький філософ, лінгвіст, перекладач, колишній викладач філософії університету Париж-Захід Нантер ла Дефанс

Пьер Косса, известный франиузский философ, лингвист, переводчик, бывщий преподаватель философии университета Западный Париж - Нантер-ля-Дефанс 